\title{
KEMAJUAN BELAJAR SISWA PADA GEOMETRI TRANSFORMASI MENGGUNAKAN AKTIVITAS REFLEKSI GEOMETRI
}

\author{
Irkham Ulil Albab, Yusuf Hartono, dan Darmawijoyo \\ Universitas Sriwijaya \\ email: irkhamulilalbab@gmail.com
}

\begin{abstract}
Abstrak: Penelitian ini bertujuan untuk mendeskripsikan kemajuan belajar siswa pada materi geometri transformasi yang didukung dengan serangkaian aktivitas belajar berdasarkan Pendidikan Matematika Realistik Indonesia. Penelitian didesain melalui tiga tahap, yaitu tahapan perancangan desain awal, pengujian desain melalui pembelajaran awal dan pembelajaran eksperimental, dan tahap analisis retrospektif. Dalam penelitian ini, Hypothetical Learning Trajectory, HLT (HLT) berperan penting sebagai desain pembelajaran sekaligus instrumen penelitian. HLT diujikan terhadap 26 siswa kelas VII. Data dikumpulkan dengan teknik wawancara, pengamatan, dan catatan lapangan. Hasil penelitian menunjukkan bahwa desain pembelajaran ini mampu menstimulasi siswa untuk memberikan karakteristik refleksi dan transformasi geometri lainnya secara informal, mengklasifikasikannya dalam transformasi isometri pada level kedua, dan menemukan garis bantuan refleksi pada level yang lebih formal. Selain itu, garis bantuan refleksi digunakan oleh siswa untuk menggambar bayangan refleksi dan pola pencerminan serta memahami bentuk rotasi dan translasi sebagai kombinasi refleksi adalah level tertinggi.
\end{abstract}

Keyword: transformasi geometri, kombinasi refleksi, rotasi, translasi, design research, HLT

\section{STUDENTS' LEARNING PROGRESS ON TRANSFORMATION GEOMETRY USING THE GEOMETRY REFLECTION ACTIVITIES}

\begin{abstract}
This study was aimed at describing the students' learning progress on transformation geometry supported by a set of learning activities based on Indonesian Realistic Mathematics Education. The study was designed into three stages, that is, the preliminary design stage, the design testing through initial instruction and experiment, and the restrospective analysis stage. In this study, Hypothetical Learning Trajectory (HLT) played an important role as an instructional design and a research instrument. HLT was tested to 26 seventh grade students. The data were collected through interviews, observations, and field notes. The findings of the study showed that this instructional design could stimulate students to provide reflection characteristics and other transformation geometry informally, to classify them in the transformation isometry in the second level, and to find the reflection supporting line in the more formal level. In addition, the reflection supporting line was used by the students to draw the reflection image and the mirroring pattern and to understand the rotation and translation shapes as a combination of reflection at the highest level.
\end{abstract}

Keyword: geometric transformation, rotation, translation, and HLT

\section{PENDAHULUAN}

Pengetahuan mengenai transformasi geometri sangat berguna bagi siswa untuk membangun kemampuan spasial, kemampuan penalaran geometri, dan memperkuat pembuktian matematika (Edward, 1997:187). Kemampuankemampuanitu(Patterson, 1973:90) dapat membuat siswa mengeksplorasi konsep matematika abstrak tentang konsep kongruen, simetri, kesebangunan, dan garis paralel; memperkaya pengalaman, pemikiran dan imaginasi geometri siswa; serta meningkatkan kemampuan spasial siswa. Berkaitan dengan hal tersebut, konsep geometri transformasi harus benar-benar dikuasai oleh siswa. Akan tetapi, memahami konsep geometri transformasi masih sulit bagi siswa.

Penelitian mengungkapkan bahwa siswa mengalami kesulitan dalam memahami konsep dan variasi yang dimunculkan dan kesulitan dalam mengidentifikasi transformasi meliputi translasi, refleksi, rotasi dan kombinasi trans- 
formasi tersebut (Clements \& Burns, 2000:42; Olson, Zenigami \& Okazaki, 2008:25; Rollick, 2009:397). Selain itu, siswa kurang memahami bagaimana suatu bangun direflesksikan ataupun dicerminkan.

Penelitian yang dilakukan oleh Morris dan Paulsen (2011:129) mengungkapkan bahwa beberapa siswa sudah bisa melakukan transformasi untuk objek geometris yang sederhana, akan tetapi mereka mengalami kesulitan ketika menemukan permasalahan rotasi dan refleksi untuk bangun yang lebih kompleks. Selain itu, siswa juga mengalami kesulitan dalam membangun bukti transformasi geometris secara aljabar (Naidoo, 2010:40). Pembuktian secara aljabar yang merupakan bukti yang bersifat umum sangat penting untuk meningkatkan kemampuan pembuktian matematis. Sebagai contoh siswa belum dapat menggeneralisasikan bahwa refleksi titik $\mathrm{A}(\mathrm{x}, \mathrm{y})$ ke sumbu $\mathrm{X}$ akan menghasilkan bayangan $A^{\prime}(x,-y)$. Kesulitan lain yang dialami oleh siswa salah satunya berkaitan dengan arah transformasi (Schultz, 1983:99).

Sebagai hasil dari perkembangan kurikulum pendidikan di dunia, kurikulum di Indonesia juga mengalami perubahan yang dramatis sejak 2013. Kurikulum saat ini, menitikberatkan pada pembelajaran dengan situasi spesifik untuk kemudian menarik simpulan secara keseluruhan melalui pendekatan ilmiah (Kemdikbud, 2013:185). Tidak seperti pembelajaran tradisional dimana retensi informasi hanya sekitar 10 persen setelah 15 menit sementara itu ukuran perolehan pemahaman kontekstual sebesar 25 persen, tetapi pada pembelajaran berbasis pendekatan ilmiah, retensi informasi dari guru sebesar lebih dari 90 persen setelah dua hari dan perolehan pemahaman kontekstual sebesar 50-70 persen (Kemdikbud, 2013:185).

Situasi spesifik yang disajikan dalam pendekatan ilmiah tersebut dapat dilakukan dengan Pendidikan Matematika Realistik Indonesia (PMRI). PMRI yang merupakan adaptasi dari Pendekatan Realistic Mathematics Education, menyarankan bahwa daripada mengajar dari level formal, lebih baik, siswa diajari dari level informal dimana mereka mengenalnya di kehidupan sehari-hari (Gravemeijer, 2010:42).
Pengajaran Geometri transformasi menggunakan PMRI telah membantu siswa dalam memahami dan membangun konsepnya. Zulkardi (2002:93) mengungkapkan bahwa banyak siswa lebih bisa mengungkapkan pendapat dan yang paling penting mereka mampu memecahkan masalah geometri transformasi sendiri. Selain itu, Helsa dan Yusuf (2011:93) mengemukakan bahwa melalui aktivitas-aktivitas yang didesain dengan PMRI siswa terlatih untuk berargumentasi dan berpikir kritis selain pembelajarannya menarik dan membuat siswa antusias. Pembelajaran geometri dengan pendidikan matematika realistik juga sudah terbukti berhasil meningkatkan prestasi belajar siswa (Sarjiman, 2006:89; Supardi, 2012:244; Syahputra, 2013: 365)

Transformasi Geometri memiliki banyak peranan dalam perkembangan matematika siswa. Edwards (1997:187) mengungkapkan bahwa belajar transformasi geometri menyediakan kesempatan luas bagi pelajar untuk mengembangkan kemampuan visualisasi spasialnya dan penalaran geometri untuk memperoleh kemampuan pembuktian matematis. Selain itu, ada tiga alasan utama mengapa siswa harus belajar geometri transformasi seperti yang disampaikan Hollebrands (2003:55), yaitu memberikan kesempatan siswa untuk berpikir tentang konsep matematika yang penting (seperti simetri, fungsi, dan sebagainya), menyediakan konteks yang membuat siswa berpikir menyadari bahwa geometri transformasi melibatkan berbagai disiplin ilmu, dan memungkinkan siswa terlibat pada aktivitas yang menggunakan reasoning tingkat tinggi melalui berbagai variasi. Bahkan menurut NCTM (2000:41), "Program pengajaran mulai TK hingga SMA harus bisa membuat siswa mampu menggunakan transformasi dan simetri untuk menganalisis situasi matematis".

Penelitian ini berfokus pada transformasi geometri yang tidak tidak mengubah ukuran atau disebut transformasi isometri. Suatu transformasi dapat disebut sebagai suatu isometri jika transformasi tersebut mengirim sembarang dua titik $\mathrm{P}_{1}$ dan $\mathrm{P}_{2}$ ke titik $\mathrm{f}\left(\mathrm{P}_{1}\right)$ dan $\mathrm{f}\left(\mathrm{P}_{2}\right)$ dengan jarak antartitik bayangan sama dengan 
jarak antar titik asalnya. Dengan kata lain adalah:

$$
|f(P 1) f(P 2)|=|P 1 P 2|
$$

(Stillwell, 2005:144).

Selama ini, telah ketahui ada beberapa tipe transformasi geometri yaitu translasi (perpindahan), refleksi (pencerminan), rotasi (perputaran) serta dilatasi (perbesaran). Dengan fokus penelitian pada transformasi isometri maka dilatasi tidak dibahas dalam penelitian. Pengelompokan ini dapat dilihat dalam Gambar 1.

Sementara itu, Kahfi (1997:105) menyebutkan dalam penelitiannya bahwa dalam $\mathrm{R}\{2\}$, pencerminan merupakan generator isometri (refleksi, translasi, rotasi dan refleksi-translasi). Jika $g$ adalah suatu isometri dalam bidang, komposisi dari $\mathrm{f}$ dan $\mathrm{g}$ atau $f$ o $g$ juga merupakan isometri (Blanco, 2011:2). Oleh karena itu translasi maupun rotasi yang disusun dari komposisi pencerminan juga isometri. Suatu translasi memindahkan setiap titik pada bidang dengan mempertahankan ukuran dan arah (Stillwell, 2005: 58). Translasi membawa titik $(x, y) \mathrm{ke} \operatorname{titik}(x+a, y+b)$. Translasi merupakan isometri tanpa titik tetap (Blanco, 2011:2). Sementara itu rotasi adalah isometri dengan sebuah titik tetap yang merupakan pusat rotasi. Untuk rotasi pengetahuan awal siswa adalah mengenal sudut $90^{\circ}, 180^{\circ}, 270^{\circ}$ and $360^{\circ}$ termasuk arah putar rotasi (Morris dan Paulsen, 2011:129).

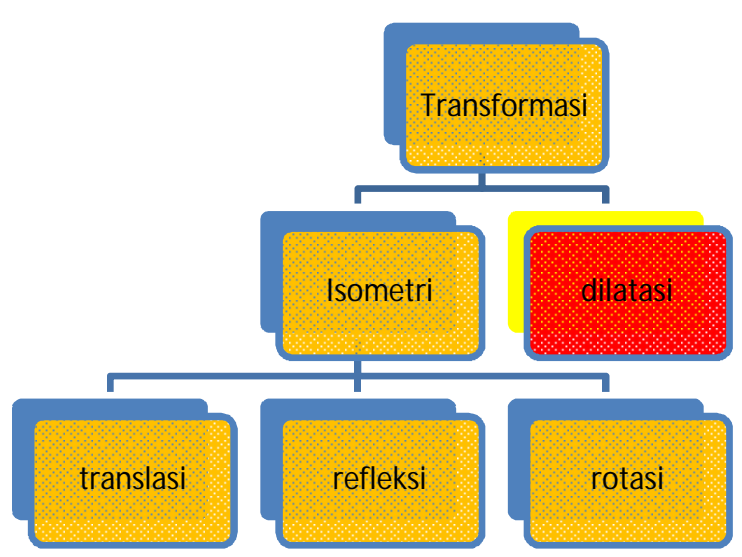

Gambar 1. Pengelompokan Jenis Geometri Transformasi Berdasarkan Isometri
Dalam pengajaran pencerminan di sekolah dasar, konsep pencerminan diajarkan melalui garis simetri. Morris dan Paulsen (2011:129) mendesain pembelajaran transformasi dengan menggunakan bantuan tracing paper dengan tujuan agar siswa terbantu secara visual. Bantuan visualisasi berperan penting dalam pembelajaran Transformasi Geometri. Di dalam desain tersebut, objek yang diamati sebagai objek transformasi adalah bentuk poligon. Hal tersebut serupa dengan penemuan Thaqi (2011:9) yang juga menyimpulkan dalam penelitiannya bahwa para pendidik lebih bisa mengajarkan geometri transformasi dengan bantuan gambar. Dia berpendapat bahwa untuk mempelajari transformasi, siswa bisa menemukan sifat-sifat bayangan transformasi melalui visual. Sementara itu, menurut Naidoo (2010: 40), strategi yang paling efektif dalam pembelajaran transformasi geometri adalah gabungan antara visual dan analitik. Strategi dengan bantuan visual dan analitik sudah bisa dilakukan untuk siswa smp karena siswa sudah mampu berpikir abstrak.

Dengan memperhatikan permasalahan bahwa pengajaran yang dilakukan selama ini masih bersifat formal, saatnya pembelajaran Matematika itu bergerak dari transfer pengetahuan menuju pengajaran yang bermakna (Sembiring, Hoogland, \& Dolk, 2010:41). Oleh karena itu, perlu adanya inovasi agar pengajaran Matematika menjadi lebih bermakna melalui PMRI. Teori pembelajaran PMRI diawali dari hal-hal yang riil atau pernah dialami siswa, menekankan pada keterampilan proses, berdiskusi, berkolaborasi, beragumentasi dengan teman sekelas sehingga pada akhirnya siswa menemukan sendiri penyelesaian suatu masalah menggunakan matematika. Kebermaknaan konsep matematika merupakan konsep utama dari PMRI. Proses belajar siswa hanya akan terjadi jika pengetahuan (knowledge) yang dipelajari bermakna bagi siswa (Freudenthal, 1991:45).

Prinsip PMRI sejalan dengan prinsip yang ada dalam Realictic Mathematics Education (RME). Terdapat dua pandangan yang penting dari Freudenthal yaitu (1) mathematics must be connected to reality; and (2) mathe- 
matics as human activity" (Zulkardi, 2002:9). Situasi kehidupan siswa tidak selalu harus hal yang nyata bagi siswa, semua hal yang dapat dibayangkan atau terjangkau oleh imajinasinya juga merupakan sesuatu yang riil bagi siswa. Pandangan kedua mempunyai makna bahwa matematika merupakan suatu aktivitas manusia dimana siswa diberikan suatu kesempatan untuk belajar di dalam aktivitas matematika. Dengan demikian diharapkan siswa dapat menemukan konsep atau ide matematika yang kemudian disebut model-of pemikiran siswa.

Karakteristik PMRI. Bakker (2004:6) mengemukakan bahwa terdapat lima karakteristik dalam pembelajaran matematika realistik yang digunakan sebagai landasan dalam merancang pembelajaran (instructional design) yang kemudian diadopsi menjadi prinsip utama PMRI, yaitu sebagai berikut.

- Phenomenological exploration or the use of contexts (menggunakan masalah kontekstual): Masalah kontekstual digunakan sebagai titik tolak munculnya suatu konsep matematika. Kegiatan matematika dimulai dari situasi yang pernah dialami atau dapat dibayangkan siswa.

- The use of the models or bridging by vertical instruments (menggunakan model): Dalam pembelajaran matematika melalui pendekatan PMRI, rumus matematika tidak ditransfer secara langsung. Siswa diarahkan pada pengembangan model, skema, dan simbolisasi. Penggunaan model bertujuan untuk menjembatani dari tahap kongkret ke tahap formal. Model matematik yang diperoleh $d i$ kembangkan oleh siswa sendiri.

- The use of the students own productions and constructions or students contribution (menghargai ragam jawaban dan kontribusi siswa): Kontribusi yang besar pada proses belajar mengajar diharapkan dari konstruksi siswa sendiri yang mengarahkan mereka dari metode informal mereka ke arah yang lebih formal.

- The interactive character of the teaching process or interactivity (interaktivitas): Da- lam pembelajaran, interaksi antar siswa maupun interaksi antara siswa dan guru sangatlah dibutuhkan guna berjalannya pembelajaran yang komunikatif. Bentuk interaksi dapat berupa negosiasi secara eksplisit, intervensi, diskusi, memberikan penjelasan, komunikasi, kooperatif dan evaluasi.

- The intertwining of various learning strands (terintegrasi dengan topik pembelajaran lainnya). Pengintegrasian materi pembelajaran akan membantu siswa untuk mempelajari matematika dengan cara yang efektif. Dalam aktivitas pembelajaran, materi akan dikaitkan dengan pengetahuan lainnya seperti aturan kesejajaran, simetri dan hubungan antara pencerminan dengan rotasi dan translasi. Dengan demikian unit-unit belajar tidak akan dapat dicapai secara terpisah tetapi keterkaitan dan keterintegrasian harus dieksploitasi dalam pemecahan masalah.

Widjaja, Dolk itu, \& Fauzan (2010:168) menemukan bahwa konteks yang bermakna memunculkan pemikiran matematis dan diskusi di antara siswa. Jika hal ini dikombinasikan dengan pertanyaan guru terkait dengan ide-ide matematika, itu akan memungkinkan siswa untuk berpikir pada tingkat pendekatan matematika yang berbeda. Para siswa diberi kebebasan dan kesempatan untuk menangani dan mengalami masalah mandiri. Namun, bukan berarti guru tidak menyediakan bantuan untuk mereka. Guru memiliki peran penting untuk membantu dan membimbing siswa, efek pemikiran dan pemahaman. Dalam studi ini, guru membantu siswa dengan mengajukan pertanyaan menyelidik. Dengan demikian, para siswa mulai berpikir tentang ide-ide matematika yang diusulkan.

Gravemeijer (2010:40) mengemukakan bahwa untuk mengembangkan kemampuan matematika formal, ada empat tahapan (level) dalam pembelajaran yaitu level situasional, model of, model for, dan formal seperti ditunjukkan Gambar 2. 

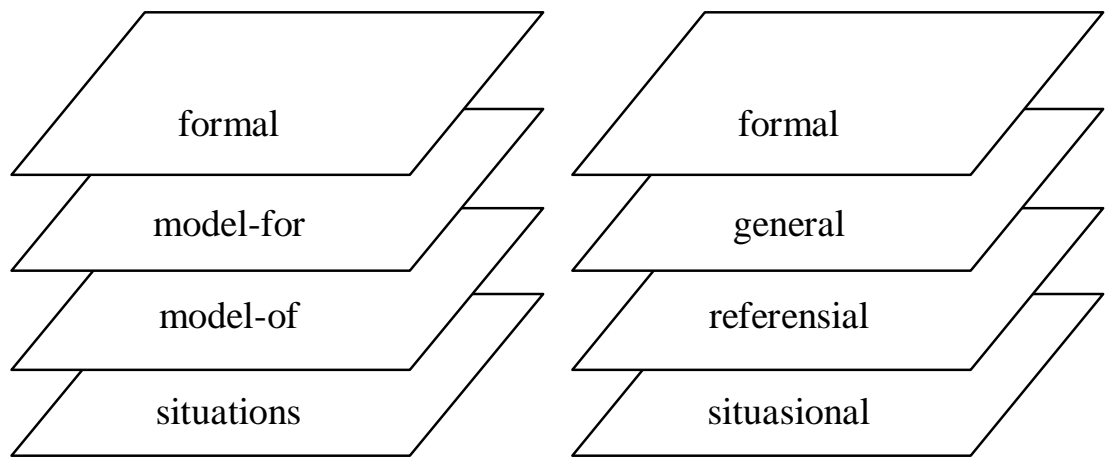

Gambar 2. Level Pengembangan Matematika Formal

Implementasi dari keempat level tersebut adalah sebagai berikut.

- Situasional level, level dasar dari emergent modeling yang muncul dimana domainspesifik, pengetahuan yang berdasarkan situasi dan strategi-strategi yang bersifat situasional digunakan di dalam penyelesaian konteks yang disajikan.

- Referential level, penggunaan model-model dan strategi-strategi pada level ini mengacu pada situasi yang menggambarkan permasalahan.

- General level, berfokus pada strategi-strategi yang sudah bersifat matematika dari referential level yang nantinya berkembang menjadi model formal.

- Formal level, ini siswa bekerja dengan prosedur-prosedur konvensional dan notasi tanpa memerlukan konteks.

\section{METODE}

Design Research dipilih sebagai metode penelitian. Peneliti mengikuti tiga fase penelitian (Gravemeijer dan Cobb, 2006:19), yaitu tahapan perancangan desain awal (preliminary design ), pengujian desain melalui preliminary teaching dan teaching experiment, dan tahap retrospective analysis.

Pada awalnya suatu dugaan lintasan belajar (Hypothetical Learning Trajectory, $H L T$ ) dibuat sebagai desain sekaligus instrumen penelitian. Pada tahap perancangan desain awal, HLT menjadi patokan pembuatan perangkat pembelajaran. Selama tahap preliminary teach- ing dan teaching experiment, HLT berperan sebagai acuan bagi guru dan peneliti untuk fokus pada apa yang akan diajarkan, diwawancarakan, serta diobservasikan. Pada tahap retrospective analysis, HLT berperan sebagai pedoman fokus analisis (Bakker, 2004:40).

Sebanyak 40 siswa kelas VII SMP dilibatkan dalam penelitian ini di mana 6 siswa berpartisipasi dalam preliminary design dan 26 siswa berpartisipasi dalam classroom teaching experiment. Penelitian ini dibantu oleh seorang guru model dan dilakukan di akhir semester gasal hingga awal semester genap tahun ajaran 2013/2014 di SMPN 1 Palembang, Sumatera Selatan. Data yang dikumpulkan di penelitian ini berupa wawancara terhadap guru dan siswa, observasi kelas yang meliputi catatan lapangan dan lembar aktivitas siswa. Data yang telah dikumpulkan kemudian dianalisis. Temuan dan catatan terhadap penelitian dijadikan simpulan untuk menjawab pertanyaan penelitian.

Hipotesis Lintasan Belajar. Untuk menelusuri kemajuan belajar siswa pada geometri transformasi melalui kombinasi refleksi, kami merancang dua pertemuan pembelajaran dimana tiap pertemuan memiliki dua aktivitas.

\section{- Pelajaran I: Peristiwa Transformasi da- lam Kehidupan Sehari-hari}

- Aktivitas 1: Mengenali tipe-tipe transformasi dan mengelompokkannya dalam isometri 
Tujuan: Siswa memahami tipe-tipe transformasi dengan memberikan ciri-ciri masing-masing jenis transformasi.

- Aktivitas 2: Memahami prinsip isometri dalam refleksi

Tujuan: Siswa menemukan sifat isometri dalam pencerminan.

\section{- Pelajaran 2: Peristiwa Pencerminan Ob- jek Geometri}

- Aktivitas 3: Menggambar bayangan refleksi sumbu $X$, sumbu $Y$, garis $\mathrm{x}=\mathrm{y}$, garis $\mathrm{x}=2$, garis $\mathrm{x}=5$.

Tujuan: Siswa dapat menggambar bayangan hasil pencerminan dengan benar

- Aktivitas 4: Mempolakan refleksi dan menggenerasinya sebagai rotasi atau translasi

Tujuan: Siswa dapat menemukan pola refleksi serta mengenali bayangan hasil kombinasi refleksi sebagai rotasi dan translasi.

Tampaknya dapat diduga bahwa dengan aktivitas-aktivitas tersebut siswa dapat terbantu dalam membangun konsep geometri transformasinya melalui kombinasi refleksi.

\section{HASIL DAN PEMBAHASAN}

Dalam aktivitas pertama, yaitu pengenalan peristiwa transformasi, dimana aspek yang dibahas dipersempit ke dalam dua pembahasan, yaitu ukuran dan posisi orientasi bayangan, semua dugaan pemikiran siswa terjadi di aktivitas pembelajaran. Sebagaimana saran dari Freudenthal (Zulkardi, 2002:9) penggunaan konteks fenomena transformasi di alam seperti bayangan benda, kincir angin, memindahkan benda serta memperbesar-mengecilkan ukuran benda menjadikan siswa lebih mudah memberikan ciri transformasi sesuai kemampuan siswa. Level informal ini telah memberikan pemahaman awal siswa dalam memahami transformasi geometri berdasarkan kajian ukuran dan orientasi bangun. Strategi informal ini sangat baik dijadikan sumber untuk pemahaman selanjutnya. Gambar 3 memperlihatkan definisi refleksi secara secara informal oleh siswa.

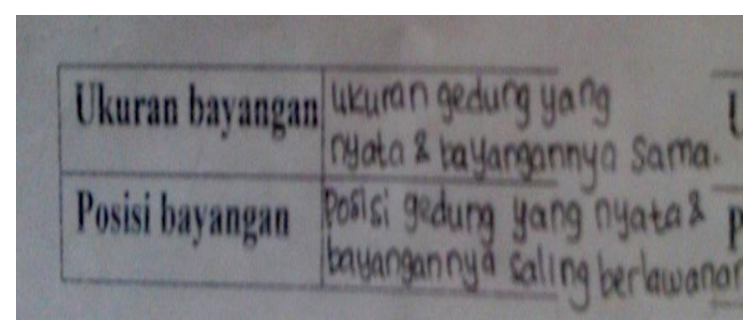

Gambar 3. Pengertian Refleksi secara Informal

Siswa mendeskripsikan refleksi memiliki ukuran bayangan yang sama dengan benda tetapi memiliki arah yang saling berlawanan. Pernyataan siswa cukup meyakinkan penulis bahwa siswa telah mampu mengenali refleksi dengan benar menurut pemahaman mereka yakni ukuran bayangan yang tetap serta orientasi arah berlawanan. Dengan bekal ciri-ciri tiap transformasi ini, siswa berhasil mengelompokkan refleksi, translasi dan rotasi dalam satu kesamaan sifat bayangan yang tidak mengubah ukuran, yaitu isometri (Stillwell, 1997:144). Strategi yang dimunculkan siswa antara lain, memutar-mutar kertas kerja, memperagakan putaran kincir angin, menggunakan penggaris, dan sebagainya.

Level kedua dijabarkan dalam aktivitas kedua. Di aktivitas ini pemikiran siswa di HLT seperti di kegiatan pembelajaran. Siswa mampu memahami konsep isometri dengan membuktikan kesamaan ukuran bayangan (Stillwell, 1997:144), meliputi lebar ataupun tinggi gedung. Melalui aktivitas ini siswa menemukan garis (tegak lurus sumbu cermin) penghubung titik pada bayangan yang bersesuaian dengan bayangan. Selama aktivitas dua, strategi yang muncul adalah, siswa menandai dua titik pada bayangan dan titik yang bersesuaian dengannya. Untuk menghitung ukuran panjangnya siswa menggunakan grid dan diberi garis bilangan. Selain itu siswa juga menggunakan garis refleksi sebagai sumbu simetri. Sumbu simetri digunakan dengan melipat kertas kerja. Sebagai ilustrasi, Dialog 1 dan Gambar 4 dapat menjelaskannya 


\section{Dialog 1. Penemuan Garis Bantuan Refleksi}

Mufidah : "Bagaimana posisi garis tersebut terhadap sumbu simetri? "“

Adinda : "Itu, kalau dilipat harus bagaimanakah? “

Mufidah : "Kalau misalnya lipat (garis) C1, tidak mungkinlah seperti ini. Kita tidak bisa“.

Auvan : "Sumbu simetrinya garis ini kan (sambil menunjuk batas sungai), tapi bagaimana posisi garis terhadapnya? di bawah kali (garis simetri)! “

Peneliti : "Coba kalian perhatikan itu, yang tadi itu (menunjuk ke papan tulis gambar diagram cartesius). Yang ada posisi sumbu $\mathrm{X}$ terhadap sumbu $\mathrm{Y}$, itu apa tadi? Bagaimana posisinya? “

Mufidah : "Tegak lurus".

Dhanya : "oooh".

Mufidah : "Berarti posisi sumbu simetri,. ".

Maulidina : "Tegak lurus".

Adinda : "Posisi dari

Mufidah : "Posisi terhadap sumbu simetri tegak lurus"

Adinda, Auvan: "posisi garis terhadap sumbu simetri tegak lurus“.

Dari kutipan dialog tersebut, diketahui Mufidah dan teman-temannya memulai diskusi dengan menyatakan adanya sifat simetri. Dari sifat simetri diskusi berjalan menuju garis simetri. Dengan menghubungkan dua titik yang bersesuaian, mereka menemukan garis yang posisinya tegak lurus terhadap sumbu simetri. Garis tersebut, pada aktivitas selanjutnya menjadi garis bantuan untuk menggambar bayangan. Bukti ini diperkuat dengan Gambar 4, yaitu dengan adanya garis-garis vertikal yang menghubungkan titik pada benda dengan titik yang bersesuaian pada bayangan. Beberapa bagian juga terlihat garis-garis vertikal yang posisinya tegak lurus sumbu cermin.

Di aktivitas ketiga, sebagai model menuju tahapan formal, sedikit terjadi penyimpangan HLT terhadap aktivitas pembelajaran. Siswa bisa menggambar bayangan dengan benar untuk semua jenis refleksi yang disajikan. Hal ini dikarenakan penulis mempertimbangkan temuan Morris dan Paulsen (2011:129) untuk menggunakan objek sederhana agar lebih mu- dah dimengerti siswa. Oleh sebab itu, bayangan hasil refleksi siswa memiliki ukuran dan orientasi yang tepat. Meskipun demikian, sejumlah kecil siswa masih mengalami kesulitan orientasi bayangan seperti ditunjukkan dalam Dialog 2 sebelum akhirnya siswa bisa.

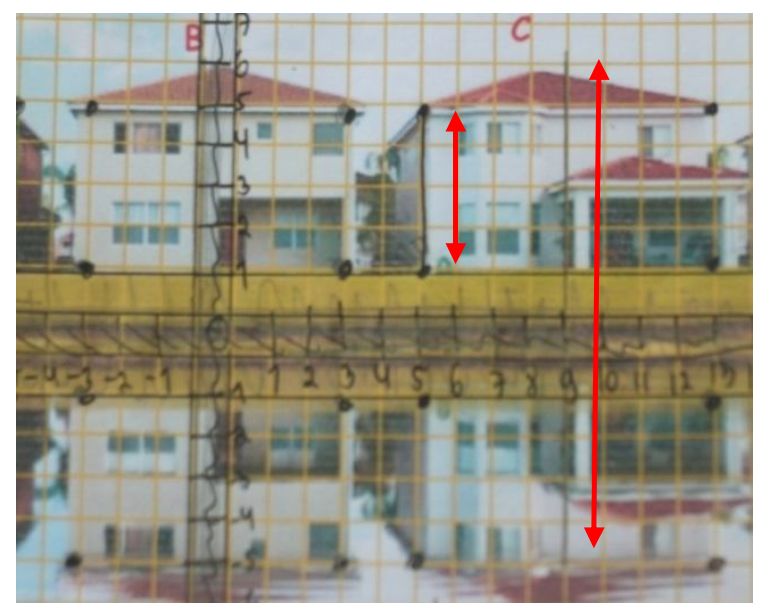

Gambar 4: Penanda-penanda dan Garis Tegak Lurus yang Dibuat untuk Membandingkan Ukuran Bayangan dan Benda

\section{Dialog 2. Kesalahan Merefleksikan Bayang-} an di $y=x$

Siswa : "A nya di sini, C nya di sini (menunjuk ke bayangan) "

Peneliti : "C di?"

Siswa : "C di sini (menunjuk titik yang bukan seharusnya) "

Peneliti : "C ko bisa di situ? “

Siswa : "Bukan-bukan"

Peneliti : "B dulu, yang dekat dulu"

Siswa : "Oh, yang deket dulu"

Peneliti : "B dulu dimana? B yang ini kan?"

Siswa : "Iya"

Peneliti : "B itu jadi dimana? “

Siswa : B di sini (menunjuk ke titik yang bukan seharusnya)

Peneliti : "Hmm? jauhnya? "

Siswa : "Kan A di sini. "

Dari dialog tersebut siswa mengalami kesalahan meletakkan titik bayangan yang bersesuaian dengan benda. Seperti terlihat pada baris ketiga, siswa salah menempatkan titik $\mathrm{C}$ pada posisi yang benar. Kesulitan orientasi ini juga diungkapkan Schultz (1983:99) dan Ed- 
ward (1991:122). Selain itu, di aktivitas menggambar bayangan ini, beragam strategi dimunculkan siswa yaitu menggunakan garis bantuan (yang ditemukan di aktivitas 2), melipat kertas kerja serta memanfaatkan grid. Salah satu strategi siswa ditunjukkan pada Gambar 5, yaitu garis bantuan garis putus-putus.

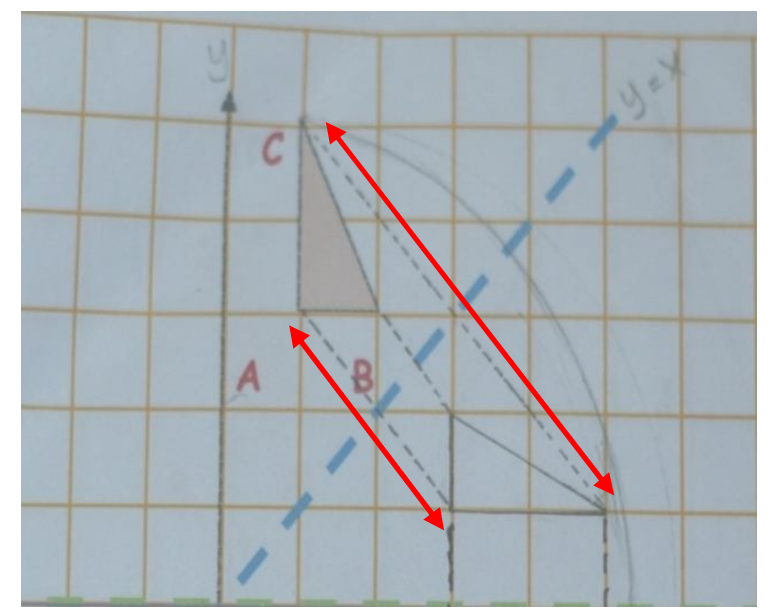

Gambar 5. Garis Bantuan untuk Menggambar Bayangan

Pada aktivitas terakhir, sebagai level formal, HLT tidak tercapai sepenuhnya tetapi pemahaman yang dimaksud sudah diperoleh. Kombinasi dari refleksi sebagai generator rotasi dan translasi (Kahfi, 1997:105; Blanco, 2011:2) sudah bisa ditemukan oleh siswa. Gambar hasil transformasi sudah dibuat dengan benar oleh siswa sehingga sifat translasi maupun rotasi dapat mereka sadari. Sebelumnya siswa berhasil mempolakan refleksi terhadap sumbu $\mathrm{X}$, Y dan $\mathrm{x}=\mathrm{y}$ seperti ditunjukkan Dialog 3 .

\section{Dialog 3. Menentukan Pola Bayangan Refleksi}

Peneliti : "Itu ko bisa (-a,b) bagaimana caranya? “.

Siswa 1 : "Lha itu kan mencari arah sebaliknya"

Siswa 2 : "Itu kan terbalik"

Siswa 3 : "terbalik-terbalik (nada menyalahkan)

Peneliti : "mana yang terbalik?"

Siswa 2 : "Ini dibalik (menunjuk nilai $\mathrm{x}$ dalam kolom), yang -5 jadi $5,-2$ jadi $2,-5$ jadi 5

Peneliti: "oh begitu. Jadi ini harus jadi apa yang (a,b) ?"

Siswa : "ini $(-a, b)$ "

Peneliti : "Pintar pintar"
Siswa membaca pola refleksi dengan melihat keteraturan angka koordinat yang berubah. Siswa dua menunjukkan bahwa pola terlihat dari perubahan angka absis (x) berupa perubahan tanda positif ke negatif. Pernyataan ini dapat dilihat di baris kelima dimana pernyataan tersebut sangat meyakinkan peneliti bahwa siswa benar-benar mampu mempolakan bayangan refleksi. Perbedaan HLT yang penting untuk dibahas adalah kesalahan siswa dalam mempolakan pencerminan pada sumbu $\mathrm{x}=\mathrm{a}$ (Gambar 6). Pada refleksi sumbu-sumbu lainnya seperti sumbu $\mathrm{y}$, sumbu $\mathrm{X}$, sumbu $\mathrm{x}=\mathrm{y}$, siswa tidak mengalami kesulitan. Pemberian kolom-kolom lembar aktivitas memudahkan mempolakan titik koordinat secara umum dalam bentuk aljabar di titik $(a, b)$.

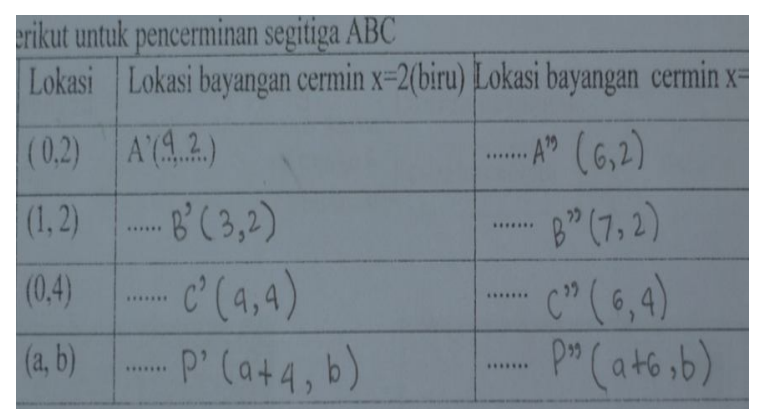
Gambar 6. Koordinat Titik Bayangan Benar,
tetapi Pola yang Dibuat Salah

Siswa memberikan alasan yang tepat yaitu dengan membaca angka yang sama dari bayangan, akan ditemukan pola. Akan tetapi, kolom-kolom pada sesi gambar refleksi garis $\mathrm{x}=\mathrm{a}$, siswa tidak bisa terbantu. Terlalu banyak variabel yang belum terpenuhi untuk memutuskan pola pencerminan tersebut. Sebagai pencapaian, siswa bisa menemukan koordinat bayangan dengan menggambarnya di diagram kartesius.

Namun, kekurangan tersebut tidak mengganggu kelanjutan pengerjaan lembar aktivitas. Siswa berhasil menggenarasi rotasi dengan ukuran sudut putar dan pusat secara benar. Strategi yang digunakan siswa adalah dengan melingkarkan jangka di titik yang diduga sebagai pusat rotasi. Sedangkan busur digunakan untuk mengukur besar sudut putar (Dialog 6). 


\section{Dialog 4. Menentukan Ukuran Rotasi dengan Melingkarkan Jangka dan Busur}

Peneliti : "Rotasi, yakin?"

Siswa 1 : "Yakin, rotasi".

Peneliti : "Kalau rotasi memutarnya dari mana? Pusat rotasinya di mana?"

Siswa 1 : "Di tengah".

Peneliti : "Di tengah.. Berapa derajat?"

Siswa 1 : "180 derajat"

Peneliti : "Coba buktikan bagaimana itu? Bagaimana memakai jangka?"

Siswa 2 : "Sini, pegang ujungnya! “

Siswa 1 : (melingkarkan jangka).

Peneliti : "Nah, pas kan? Berapa derajat itu?"

Siswa 1 : "180”.

Peneliti : "Yang A juga".

Dalam dialog tersebut siswa memahami bayangan sebagai rotasi dengan memutarkan jangka sebagai penjejak, sedangkan untuk mengetahui ukuran rotasi mereka menggunakan busur derajat. Akan tetapi, siswa tidak mampu sampai pada sintesis ukuran sudut rotasi sebesar dua kali lipat sudut apit antara dua sumbu refleksi. Sementara itu pada translasi, siswa mampu menunjukkan bahwa bayangan hasil transformasi merupakan translasi, tetapi siswa hanya menyebutkan arah translasi. Siswa belum sampai ke ukuran perpindahan akibat translasi. Peneliti kurang membahas ukuran translasi kaitannya dengan jarak dua sumbu refleksi.

\section{PENUTUP}

- Mengenali jenis-jenis transformasi melalui pemberian ciri-cirinya masing-masing sesuai pemahaman siswa serta mengelompokkannya dalam transformasi isometri berdasarkan kesamaan sifat mempertahankan jarak.

- Membuktikan bahwa sifat isometri berlaku untuk semua ukuran baik panjang maupun lebar objek transformasi.

- Menemukan garis bantuan yang berguna untuk menggambar bayangan refleksi. Garis tersebut adalah garis yang menghubungkan titik titik benda dan bayangan yang bersesuaian dimana garis tersebut tegak lurus terhadap sumbu refleksi.

- Menggambar bayangan secara tepat dan benar pada sumbu X, sumbu Y, garis $\mathrm{x}=\mathrm{y}$, garis $\mathrm{x}=\mathrm{a}$ dan garis dengan kemiringan tertentu, serta memahami orientasi bayangan secara benar.

- Menentukan pola refleksi untuk sumbu X, sumbu $\mathrm{Y}$, garis $\mathrm{x}=\mathrm{y}$, garis $\mathrm{x}=\mathrm{a}$ secara benar. Sementara untuk sumbu $\mathrm{x}=\mathrm{a}$ siswa belum bisa membuat polanya.

- Menemukan fakta bahwa refleksi adalah genarator rotasi dan translasi. Selain itu, siswa juga mengetahui pusat dan ukuran sudut rotasi.

Selain dari beberapa kemampuan tersebut, penelitian ini menemukan beberapa strategi yang dimiliki siswa selama pembelajaran.

- Siswa menghitung banyaknya grid (kotakkotak) untuk mengukur panjang atau lebar bayangan.

- Siswa menggunakan garis simetri untuk menunjukkan kesamaan ukuran bayangan dengan benda.

- Siswa menggunakan menandai dua titik yang akan diukur dan menghubungkan titik yang bersesuaian antara benda dan bayangan

- Siswa menggunakan garis bantuan untuk menghubungkan titik pada benda dengan titik yang bersesuaian pada bayangan. Titik tersebut dibuat tegak lurus terhadap sumbu refleksi dan berupa garis putus-putus.

- Siswa menggunakan cara melipat kertas aktivitas untuk menjiplak bayangan untuk sumbu refleksi.

\section{UCAPAN TERIMA KASIH}

Penulis menyampaikan ungkapan terima kasih kepada seluruh pihak yang memberikan dukungan, terutama DIKTI, Prof. Dr. Zulkardi selaku Ka. Progdi Magister Pendidikan Matematika, Dr Yusuf Hartono dan Dr. Darmawijoyo, selaku dosen pembimbing, Dolly Van Eerde dan dosen Utrecth sebagai pemberi masukan, serta rekan-rekan BIMPoME angkatan 2012 UNSRI. Ucapan terima kasih juga disampaikan kepada seluruh mitra bestari dan editor, serta redaksi Jurnal Cakrawala Pendidikan yang memberikan kesempatan untuk mempublikasikan artikel ini. 


\section{DAFTAR PUSTAKA}

Bakker, A. 2004. In Design Research in Statistics Education. On Symbolizing and ComputerTools. Amersfoort: Wilco Press.

Blanco, M. F. 2011. Symmetry Group in the Alhambra. Servicio Publicaciones Universidad de Valladolid.

Clements, D. H. \& Burns, B. A. 2000. "Students' development of strategies for turn and angle measure". Educational Studies in Mathematics, 41(1), hlm. 31-45.

Edwards, LD. 1991. "Children's learning in a computer microworld for transformation geometry". Journal for Reasearch in Mathematics Education Vol.22 No.2, hlm.122-137.

Edwards, LD.1997. "Explore Ring the Terrority before Proof: Students' Generalization in a computer Microworld for Transformation Geometry". International Journal of Computers for Mathematical Learning, 1:187-215.

Freudenthal, H. 1991. Revisiting Mathematics Education: China Lectures, Kluwer Academic Publishers, ISBN 7923-1299-6.

Gravemeijer, K., and Cobb, P. 2006. Design Research from the Learning Design Perspective. In Van den Akker, J., Gravemerijer, K., McKenney, S., \& Nieveen, N (Eds.), Educational Design Research. London: Routledge.

Gravemeijer, K. 2010. Realistic matheatics Education Theory as a Guideline for Problem-Centered, Interactive Mathematics Education. In K. H. Robert Sembiring (Ed.), A Decade of PMRI in Indonesia (pp. 41-50). Bandung, Utrecht: Ten Brink, Meppel.
Helsa dan Yusuf H. 2011. "Designing Reflection and Symmetry Learning by Using Math Traditional Dance in Primary School". IndoMS. J.M.E Vol.2 No. 1 January 2011, pp. 79-94.

Hollebrands, K. F. 2003. "High School Students' Understanding of Geometric Transformations in the Context of a Technological Environment". Journal of Mathematical Behavior, 22, hlm. 55-72.

Kahfi, M.S. 1997. "Keragaman Rumusan Pencerminan dalam R $\{3\} "$. MIPA dan Pembelajarannya, Vol 26, No 1. Malang: UM .

Kemdikbud. 2013. Materi Pelatihan Guru Implementasi Kurikulum 2013: Matematika SMP MTs. Jakarta: Kemdikbud.

Kemdikbud. 2013. Kompetensi Inti Matematika SMP MTs. Jakarta: Litbang kemdikbud.

Morris, T. \& Paulsen, R 2011. "Using Tracing Paper to Teach Transformation Geometry". Amesa Vol. 2. Johannensberg: Amesa.

Naidoo, J. 2010. Strategies Used by Grade 12 Mathematics Learners in Transformation Geometry. Natal: University of Kwazulu.

NCTM. 2000. "Principles and Standards for School Mathematics": Electronic Examples.

Olson, M., Zenigami, F. \& Okazaki, C. 2008. "Students' Geometric Thinking about Rotations and Benchmark Angles". Mathematics Teaching in the Middle School,14, hlm.24-26.

Paterson, J. C. 1973. "Informal Geometry in Grades 7-14". In K.B. Henderson (Ed.), Geometry in the Mathematics Curriculum: Thirty-Sixth Yearbook. (pp. 52-91). Washington, DC: NCTM. 
Rollick, M. B. 2009. "Toward a Definition of Reflection". Mathematics Teaching in the Middle School, 14(7), hlm.396-398.

Sarjiman, P. 2006. "Peningkatan Pemahaman Rumus Geometri melalui Pendekatan Realistik di Sekolah Dasar". Cakrawala Pendidikan, Februari 2006, Th. XXV, No. 1. hlm.89-.

Schultz, K, dkk. 1983. "Directional effect in transformation tasks". Journal Reseacrh in Mathematics Education, Vol 14 No. 2. National Council of Teachers of Mathematics. hal. 95-101.

Sembiring, R. K., Hoogland, K., \& Dolk, M. 2010. A decade of PMRI in Indonesia. Bandung, Utrecht: Ten Brink, Meppel.

Simon, M. A., \& Tzur, R. 2004. "Explicating the Role of Mathematical Tasks in Conceptual Learning: An Elaboration of the Hypotetical Learning Trajectory". Mathematical Thinking and Learning, 6(2), hlm.91-104.

Stillwell, J. 2005. The Four Pillars of Geometry. Barkeley: Springer.

Streefland, L. 1991. Fractions in Realistic Mathematics Education: A Paradigm of Developmental Research. Dordrecht, the Netherlands: Kluwer Academic Publishers.
Supardi. 2012. "Pengaruh Pembelajaran Matematika Realistik terhadap Hasil Belajar Matematika Ditinjau dari Motivasi Belajar" Cakrawala Pendidikan, Juni 2012, Th. XXXI, No. 2. hlm. 244-.

Syahputra, Edi. 2013. "Peningkatan Kemampuan Spasial Siswa melalui Penerapan Pembelajaran Matematika Realistik". Cakrawala Pendidikan, November 2013, th. XXXII, No. 3, hlm. 365-.

Thaqi, X. dan Gimenez, J. 2012. "Prospective Teacher's Understanding of Geometric Transformation". 12th International Congress on Mathematical Education. Seoul:TSG10.

Widjaja, W., Dolk, M., \& Fauzan, A. 2010. "The Role of Contexts and Teacher' Questioning to Enhance Students' Thinking". Journal of Science and Mathematics Education in Southeast Asia, 33(2), hlm. 168-186.

Zulkardi, Z. 2002. Developing a Learning Enviroment on Reaistic Mathematics Education for Indonesia Studet Teachers. Thesis. University of Twente. Nederland. 